\title{
Shifting the Fat-Tailed Distribution of Blockbuster Punitive Damages Awards
}

\author{
W. Kip Viscusi and Benjamin J. McMichael*
}

\begin{abstract}
The distribution of blockbuster punitive damages awards has fat tails similar to the distributions of losses from natural disasters. Extremely large awards occur more often and are more difficult to predict than if blockbuster awards were distributed normally. The size and predictability of awards are important factors in the U.S. Supreme Court's decisions on punitive damages. This article examines the effect of the Court's decision in State Farm $v$. Campbell on blockbuster punitive damages awards. State Farm shifts the fat tail of the distribution of blockbuster awards down (or "thins" the tail), which is consistent with a restraining effect on award size. State Farm reduces the size of blockbuster awards in general, but this reduction is most salient in the upper half of the distribution of awards. State Farm also has a negative influence on the probability of exceeding a single-digit ratio between punitive and compensatory damages. This article also examines the largest awards and considers why defendants may not pay large punitive damages awards.
\end{abstract}

\section{INTRODUCTION}

Punitive damages share with natural disasters the property that there are often extremely large outliers that are not consistent with a normal distribution. More specifically, extremely large punitive damages awards are characterized by a fat-tailed distribution. For natural disasters, these outliers take the form of extremely large losses. In the case of punitive damages, it is the magnitude of the awards that may be especially great.

In this article, we focus specifically on what Viscusi (2004), Hersch and Viscusi (2004), and Del Rossi and Viscusi (2010) have termed blockbuster punitive damages awards, that is, punitive damages awards of at least $\$ 100$ million. Much like losses from significant natural disasters, these awards are extreme outliers and potentially pose catastrophic financial risks to defendants. However, courts can limit the economic impact of these awards in two principal ways. First, U.S. Supreme Court decisions and state punitive damages limits can affect the magnitude of the awards. Second, courts can reduce or overturn these awards on appeal or through other postverdict procedures. This article

\footnotetext{
*Address correspondence to W. Kip Viscusi, University Distinguished Professor of Law, Economics, and Management, Vanderbilt University Law School, 131 21st Ave. S., Nashville, TN 37203; email: kip.viscusi@vanderbilt.edu. McMichael is JD/PhD Student, Vanderbilt Law and Economics Program.

We acknowledge a variety of helpful comments from two referees.
} 
examines the distribution and determinants of blockbuster awards and the ways in which the courts have restrained their economic impact.

Punitive damages serve a unique function in the U.S. civil justice system. They are essentially the only civil remedy that exists to punish defendants and deter future wrongdoers as opposed to compensating plaintiffs for specific harms or preventing those harms from recurring in the future. The U.S. Supreme Court has repeatedly held that states may authorize punitive damages only for the limited purposes of punishment and deterrence. Because these awards exist to punish and deter, the amount that any individual plaintiff may receive does not adhere to a well-defined formula. Unlike compensatory damages, which must be calibrated to a specific harm, adjudicators must decide what amount of damages will adequately achieve the more nebulous social goals of punishment and deterrence. When deciding what amount to award plaintiffs, adjudicators often receive very little guidance regarding the amount of punitive damages that is appropriate, leading some observers to question extremely large awards. ${ }^{1}$

The U.S. Supreme Court has never instructed lower courts on exactly how they should award punitive damages, despite the potential for extremely large awards, but it has provided some general guidance on what awards are unconstitutionally large. After authorizing punitive damages under the Constitution in its earlier cases, ${ }^{2}$ the Court began to limit the size of awards and the process by which they are awarded in the 1990s and 2000s under the Due Process Clause of the Fourteenth Amendment. Currently, three main cases state the constitutional doctrine on punitive damages: BMW of North America, Inc. v. Gore (1996), State Farm v. Campbell (2003), and Philip Morris USA v. Williams (2007). All three cases consistently hold that the only legitimate purposes for which states may authorize punitive damages are punishment and deterrence. In all three cases, the Court seeks to limit "grossly excessive" awards that violate notions of fundamental fairness, do not provide adequate notice to parties that they may be subject to large awards, and do not further the legitimate interests of the state. In limiting these excessive awards, the Court in $B M W$ provided three general guideposts that lower courts must consider when determining whether a given punitive award is "reasonable" under the Fourteenth Amendment: (1) the reprehensibility of the defendant's conduct, (2) the "disparity" between the harm inflicted on the plaintiff and the punitive damages award, and (3) the difference between the award and civil penalties authorized for similar cases. ${ }^{3}$

State Farm clarified the Court's decision in $B M W$ by explaining that the reprehensibility of the defendant's conduct is the most important factor in evaluating the reasonableness of a particular punitive damages award. State Farm will also play a central role in our

\footnotetext{
${ }^{1}$ For a discussion of the types of guidance received by adjudicators, see Sunstein et al. (2002). In general, awarding punitive damages may be efficient from the standpoint of deterrence, depending on the relationship between the probability of detecting the defendant's wrongful behavior and the amount of compensatory damages. Polinsky and Shavell (1998) provide a thorough overview of the economic theory of punitive damages, but there is little evidence that courts have adhered to the economic prescriptions for efficient levels of punitive damages.
}

${ }^{2}$ Pacific Mutual Life Ins. v. Haslip, 499 U.S. 1 (1991).

${ }^{3}$ These guideposts were initially announced in BMW of North America v. Gore, 517 U.S. 559 (1996). 
empirical analysis because it provided specific guidance with respect to the appropriate magnitude of punitive damages awards. The Court in State Farm explicitly limited punitive damages awards under the Due Process Clause, stating that "few awards exceeding a single-digit ratio between punitive and compensatory damages, to a significant degree, will satisfy due process." ${ }^{4}$ Using a generous interpretation of the Court's holding, no punitive damages award that exceeds the accompanying compensatory damages award by more than a factor of 10 will satisfy due process absent special circumstances. ${ }^{5}$ Finally, in Williams, the Court held that punitive damages may not be imposed to punish actions beyond the scope of the case before the court. This holding prevents juries from imposing large awards on unpopular defendants for actions they have taken outside of the scope of a given case.

After Williams, the Court next addressed punitive damages outside of the constitutional context in Exxon Shipping Co. v. Baker (2008), holding that under federal maritime law, courts may not impose a punitive award greater than the accompanying compensatory award (a ratio limit of 1 ). Although this decision is not binding outside of federal maritime law, lower courts may have inferred from Baker that the Supreme Court was less willing to tolerate large awards than it initially indicated in State Farm. ${ }^{6}$

In this article, we analyze the effect of the current punitive damages doctrine, primarily the State Farm decision, on blockbuster awards to determine whether it has had a significant negative impact on these awards. Del Rossi and Viscusi (2010) previously examined the impact of State Farm on an earlier sample of blockbuster awards and found that the decision was associated with a decrease in award amounts. Eisenberg and Heise (2011) and McMichael (2013) considered the effect of State Farm on more typical cases in the Civil Justice Survey of State Courts data and, in contrast to the results for blockbuster cases, found that it has not had a significant negative effect on punitive damages awards in general. $^{7}$

When examining blockbuster awards in this article, we consider a longer timeframe post-State Farm than did Del Rossi and Viscusi (2010) and examine the effect of State Farm

${ }^{4}$ State Farm Mutual Auto. Ins. Co. v. Campbell, 538 U.S. 408, 415-23 (2003).

${ }^{5}$ The Court has never clarified what exactly would constitute special circumstances that would justify exceeding the ratio limit imposed by State Farm.

${ }^{6}$ In Baker, the Court conducted a review of the literature on punitive damages and concluded that "[a] survey of the literature reveals that discretion to award punitive damages has not mass-produced runaway awards, and although some studies show the dollar amounts of punitive-damages awards growing over time, even in real terms, by most accounts the median ratio of punitive to compensatory awards has remained less than 1:1." Exxon Shipping Co. v. Baker, 554 U.S. 471, 497-98 (2008). The Court went on to impose this 1:1 ratio on punitive damages awards under federal maritime law.

${ }^{7}$ Eisenberg and Heise (2011) consider whether juries award more punitive damages than judges. As part of this analysis, they find that of the four years for which they have data on punitive damages across the country $(1992,1996$, 2001, and 2005), the difference between how judges and juries award punitive damages was statistically significant only in 2005. They consider State Farm as a possible reason for this difference but conclude that the shift in awarding behavior is not attributable to State Farm. McMichael (2013) conducts explicit tests for an effect of State Farm on punitive damages awards similar to those used here and finds no evidence of a significant negative effect and some evidence of a significant positive effect of State Farm on punitive damages award amounts. 
on the amount of punitive damages awarded in individual cases as well as on the probability that a given award involved a punitive to compensatory damages ratio of greater than 10-the limit imposed by State Farm. We find that State Farm has a negative influence on award size and the probability of exceeding a single-digit ratio for blockbuster awards.

Additionally, we explore the distribution of blockbuster punitive damages awards and find that it is similar to the distributions of losses from natural disasters and other catastrophic events. In particular, blockbuster awards follow a fat-tailed distribution, meaning that extremely large awards (catastrophic events) occur much more often than if awards were distributed normally. Thus, awards following a fat-tailed distribution are more difficult to predict than normally distributed awards. The nature of this distribution has important legal implications, as the U.S. Supreme Court has based much of its case law on the constitutional requirement that punitive damages remain predictable so that defendants have adequate notice of their potential liability. ${ }^{8}$ As the Court put it bluntly: "The real problem, it seems, is the stark unpredictability of punitive awards." ${ }^{\prime 9}$ We show that while blockbuster awards follow a fat-tailed distribution both before and after the Court's decision in State Farm, the distribution shifted to the left after State Farm, that is, the tail is not as fat, which is consistent with a restraining effect on blockbuster awards. As a consequence, after State Farm, defendants should be better able to predict extremely large punitive damages awards.

\section{Fat-Tailed Distributions and Punitive Damages}

Blockbuster punitive damages awards by their very nature are unusual outliers among all punitive damages awards. However, even within the category of awards that qualify as blockbuster awards, the distribution includes extreme outliers relative to other blockbuster awards. The extreme values of blockbuster punitive damages awards at the upper tail of the blockbuster award distribution exhibit many parallels with the distribution of losses from natural disasters and other catastrophic events. The losses from natural disasters are not normally distributed but tend to follow fat-tailed distributions. ${ }^{10}$ With these distributions, the largest loss may be several times larger than the next largest loss. For example, the 2004 Sumatra earthquake, which resulted in the deaths of 227,898 people, is the second worst earthquake on record. The worst earthquake on record, which occurred in 1976 in Tangshan, China, killed 655,000 people according to many estimates-almost three times as many as the 2004 event. ${ }^{11}$ Disasters resulting from human error also tend to follow

\footnotetext{
${ }^{8}$ See $B M W, 517$ U.S. at 560.

${ }^{9}$ Exxon Shipping Co. v. Baker, 554 U.S. 471, 499 (2008).

${ }^{10}$ See U.S. Geological Service Fact Sheet, "Natural Disasters-Forecasting Economic and Life Losses," <http:// pubs.usgs.gov/fs/natural-disasters/index.html>.
}

${ }^{11}$ See U.S. Geological Survey, Largest Earthquakes in the World Since 1900, <http://earthquake.usgs.gov/ earthquakes/world/10_largest_world.php>. 
Figure 1: Distributions of fatalities from natural disasters.

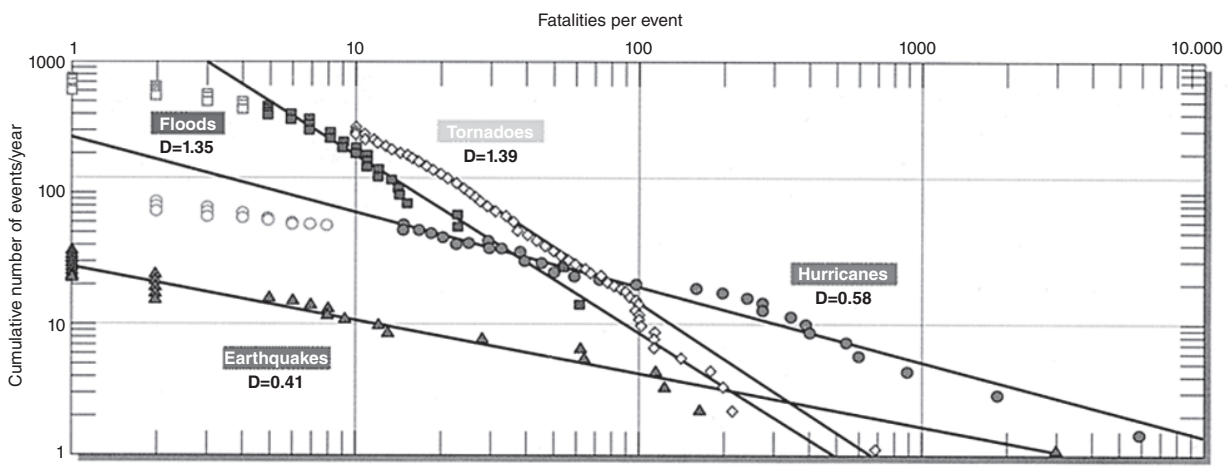

Source: U.S. Geological Service Fact Sheet, "Natural Disasters-Forecasting Economic and Life Losses," <http:// pubs.usgs.gov/fs/natural-disasters/index.html>.

fat-tailed distributions. For example, the widely publicized Deepwater Horizon disaster in 2010 caused the spill of 4.9 million barrels of oil. However, the worst oil disaster on record occurred in 1910 and resulted in the spill of 9 million barrels. ${ }^{12}$ Viscusi and Zeckhauser (2011) discuss these and other examples of large-scale losses that follow fat-tailed distributions.

In addition to natural and human-made disasters, other catastrophic events may follow fat-tailed distributions. For example, Bremmer and Keat (2009) demonstrate that volatile political events, which can have catastrophic effects on domestic and international markets, can follow a fat-tailed distribution. They note that because catastrophic political events like the confrontation between Georgia and Russia in 2008 and the 1998 Russian financial meltdown follow a fat-tailed distribution, they happen more frequently than investors-who are usually adept at handling risk-predict. They explain that fat tails "represent the risk that a particular event will occur that appears so catastrophically damaging, unlikely to happen, and difficult to predict, that many of us choose to simply ignore it" (Bremmer \& Keat 2009:2-3). While ignoring extreme or catastrophic events may be justified when they are distributed normally, doing so when they follow a fat-tailed distribution can prove problematic.

Because normal distributions do not capture the fat-tailed behavior of disasters and other catastrophic events, analyses of losses from natural disasters have employed power-law distributions, which have fat tails, to describe these losses. ${ }^{13}$ With these distributions, the event with the greatest impact may be several times as large as the next most significant event, which is a type of variation not exhibited by events that adhere to a normal distribution. The U.S. Geological Survey generated Figure 1 to demonstrate the power-law

\footnotetext{
${ }^{12}$ See World's Largest Oil Spills Map, Geology, <http://geology.com/articles/largest-oil-spills-map/>.

${ }^{13} \mathrm{~A}$ variable $p(x)$ has a power-law distribution if it can be characterized as $p(x)=c x^{\beta}$ where $c$ and $\beta$ are constants so that $\log (p(x))=\log (c)+\beta \log (x)$.
} 
Figure 2: Inverse cumulative distribution function of blockbuster punitive damages awards.

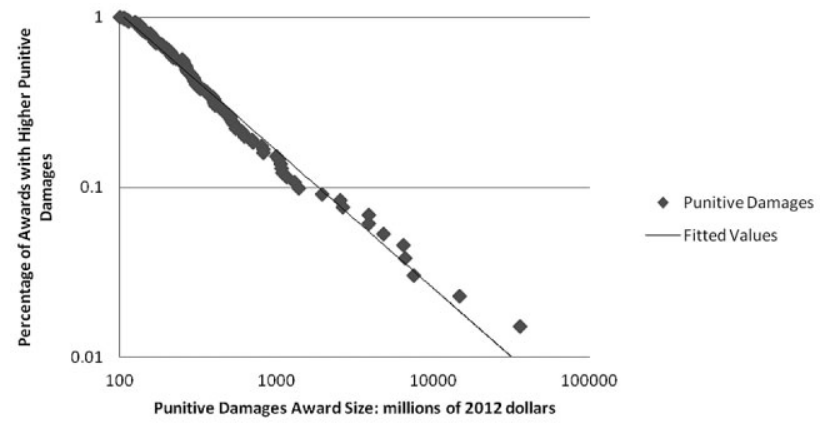

distributions of various types of natural disasters. Both axes are on a logarithmic scale so that they progress in orders of magnitude. In this graph, the measure of loss shown on the horizontal axis is the number of deaths, and the vertical axis measures the cumulative number of each type of event per year. Each set of points illustrates the power-law distribution of a different type of natural disaster, including hurricanes, tornadoes, and earthquakes. ${ }^{14}$

Blockbuster punitive damages awards likewise follow a fat-tailed distribution similar to the distribution of various natural disasters. While the cutoff for blockbuster status is a nontrivial \$100 million, many of these awards exceed this cutoff by one, two, or even three orders of magnitude. Instead of a normal distribution, or even a lognormal distribution, a power-law distribution best describes blockbuster awards.

Figure 2 illustrates the power-law distribution that blockbuster punitive damages awards follow. It reports the "inverse cumulative distribution function" of 130 blockbuster awards that we identified between 1980 and 2012 and that we analyze below. ${ }^{15}$ The "cumulative distribution function" in Figure 2 is "inverse" in the sense that each point represents the size of the award (plotted along the horizontal axis) and the proportion of awards that are smaller (plotted along the vertical axis) as opposed to the proportion of larger awards in a true cumulative distribution function. Figure 2 also plots a power trend line through the data to show how well these data are approximated by a power function. ${ }^{16}$ Both the

\footnotetext{
${ }^{14}$ The parameter D reported in the USGS's figure is the fractal dimension for the respective natural disasters. Essentially, D is a measure of the up-and-down fluctuations in the data. More fluctuations cause D to increase. The empirical measurement of D differs somewhat from the formal definition of fractal dimension for mathematically defined fractals. See Yu and Huang (2004).
}

${ }^{15}$ Where a true cumulative distribution function of random variable $\mathrm{X}$ is given by $F(x)=P(X \leq x)$, the inverse cumulative distribution function presented in Figure 2 is given by $F(x)=P(X>x)$.

${ }^{16}$ We exclude the two largest cases (Engle and Middleton, which are discussed at length below) from this figure. We exclude these cases only because doing so is necessary to construct this and later inverse cumulative distribution 
vertical and horizontal axes use a logarithmic scale so that they progress in orders of magnitude. The fact that the data are essentially linear on this logarithmic scale demonstrates the fat-tailed aspect of the distribution of blockbuster awards. ${ }^{17}$ We employ a BoxCox transformation and find that a logarithmic functional form is more appropriate than a linear form. ${ }^{18}$

Similar to the largest losses from natural disasters, the largest punitive awards may be several times larger than the next largest award. For example, consider the two largest awards in Figure 2. The largest award is $\$ 35$ billion while the second largest is $\$ 14$ billionless than half the size of the largest. Including the two largest awards (Engle v. R.J. Reynolds Tobacco and Middleton v. Collins) exacerbates the fat tail even more. These two awards are four times (Middleton) and five times (Engle) larger than the largest award presented in Figure 2.

With such large awards possible, defendants will likely not be able to predict what amount of monetary liability they may face for their actions. State policymakers and both state and federal courts have recognized that defendants may lack adequate notice of the liability they may face and have stepped in to afford a number of protections against excessive punitive damages. Many states have enacted specific tort reforms limiting the total amount of punitive damages available to plaintiffs and/or the ratio between the amount of compensatory and punitive damages. ${ }^{19}$ For example, Florida currently limits punitive damages to the higher of $\$ 500,000$ or three times the amount of compensatory damages, with these limits increasing if the defendant knew his or her actions risked injury to or intentionally injured the plaintiff. Some states, for example, Louisiana, authorize punitive damages only for certain types of cases. Nebraska has simply banned punitive damages.

functions. Because the inverse cumulative distribution function is given by $F(x)=P(X>x)$, the largest award will, by definition, have a zero probability of taking on a value larger than $x$. This zero probability is not problematic in general, but because we use logarithmic scales for both axes, we must either assign a positive probability for the largest award or remove it from the analysis. Because any probability we assign would be arbitrary, we remove the largest award (which was imposed in Engle) from the analysis. We also remove the second largest award (which was imposed in Middleton) from the analysis because we later include figures that group awards by whether they were imposed before or after State Farm, and Middleton is excluded as the largest award in the after-State Farm group. We exclude it here as well to maintain comparability between figures. However, including it here does not change the conclusion about the fat-tailed nature of the distribution of blockbuster awards.

\footnotetext{
${ }^{17}$ Figure 2 does not present the blockbuster punitive damages award data in the same manner as the USGS presented the data on natural disasters, and it is not possible to observe the fractal dimension in the inverse CDF. However, blockbuster punitive damages awards have a fractal dimension $\mathrm{D}$ equal to 1.19 , which is between that of hurricanes and floods.

${ }^{18}$ Using the Box-Cox transformation on both the left- and right-hand sides of the equation relating punitive damages to compensatory damages, we are able to reject the linear functional form much more strongly (chi-squared statistic over 1,021.06) than the logarithmic functional form (chi-squared statistic of approximately 32.97). When transforming just the left-hand side (punitive damages), we are similarly able to reject the linear functional form much more strongly than the logarithmic form, chi-squared statistics of 1084.59 (linear) and 94.02 (logarithmic).
}

${ }^{19}$ Avraham (2011) provides a comprehensive list of state tort reforms including those directed at punitive damages. 


\section{The Effect of the Current Constitutional Doctrine on Punitive Damages}

\section{A. The Blockbuster Awards}

As in previous blockbuster award studies, we identified blockbuster awards by conducting a broad and thorough search of a variety of sources, including, but not limited to: Westlaw databases, Lexis-Nexis databases, LEXIS combined jury verdicts and settlements, and VerdictSearch's annual "Top 100 Jury Verdicts" for 2009, 2010, 2011, and 2012. We obtained basic case information, including the year of the award, the state where the case was heard, the type of industry involved, and the amounts of punitive and compensatory damages. We obtained this information primarily from news articles and, where possible, court documents. Our search yielded a total of 32 new blockbuster awards, which, combined with previously identified awards in Del Rossi and Viscusi (2010), brings the total to 132 blockbuster awards. Of these 32 new awards, eight were imposed between 1981 and 2008 and were not identified in previous work. Twenty-four of the newly identified awards occurred between 2009 and 2012, which was beyond the timeframe considered in earlier studies.

Before delving into the analysis of the effect of the State Farm decision on punitive damages awards, we report in Table 1 and Figure 3 a basic overview of the distribution of blockbuster punitive damages awards. Table 1 organizes the 132 awards we have identified into deciles-with the first group having two more awards than the others-and reports basic statistics for each. The increase in means between the lower deciles and the higher deciles illustrates how quickly blockbuster awards increase at the higher end of the distribution. For example, the increase (in \$millions) in the mean between deciles is never more than 50 below the sixth decile, while the increase is 152 between the seventh and eighth, 469 between the eighth and ninth, and over 30,000 between the ninth and tenth. This huge jump in the final decile reflects the fat-tailed nature of the distribution. The ranges covered by the deciles tell a similar story.

Table 1: Summary Statistics for Deciles of Blockbuster Punitive Damages Awards ${ }^{\mathrm{a}}$

\begin{tabular}{lrrrrrr}
\hline Decile & Mean & Median & Sum & Minimum & Maximum & Number \\
\hline First & 118 & 114 & 1,770 & 100 & 133 & 15 \\
Second & 142 & 140 & 1,851 & 134 & 158 & 13 \\
Third & 166 & 166 & 2,157 & 159 & 183 & 13 \\
Fourth & 201 & 204 & 2,612 & 186 & 212 & 13 \\
Fifth & 249 & 255 & 3,242 & 217 & 267 & 13 \\
Sixth & 290 & 293 & 3,771 & 267 & 312 & 13 \\
Seventh & 376 & 389 & 4,885 & 316 & 432 & 13 \\
Eighth & 528 & 519 & 6,865 & 450 & 625 & 13 \\
Ninth & 997 & 1,036 & 12,958 & 700 & 1,378 & 13 \\
Tenth & 33,625 & 6,401 & 437,131 & 1,945 & 193,329 & 13 \\
\hline
\end{tabular}

${ }^{\text {a Damages are reported in millions of } 2012 \text { dollars and rounded to the }}$ nearest million. 
Figure 3: Histogram of blockbuster punitive damages awards (log amounts).

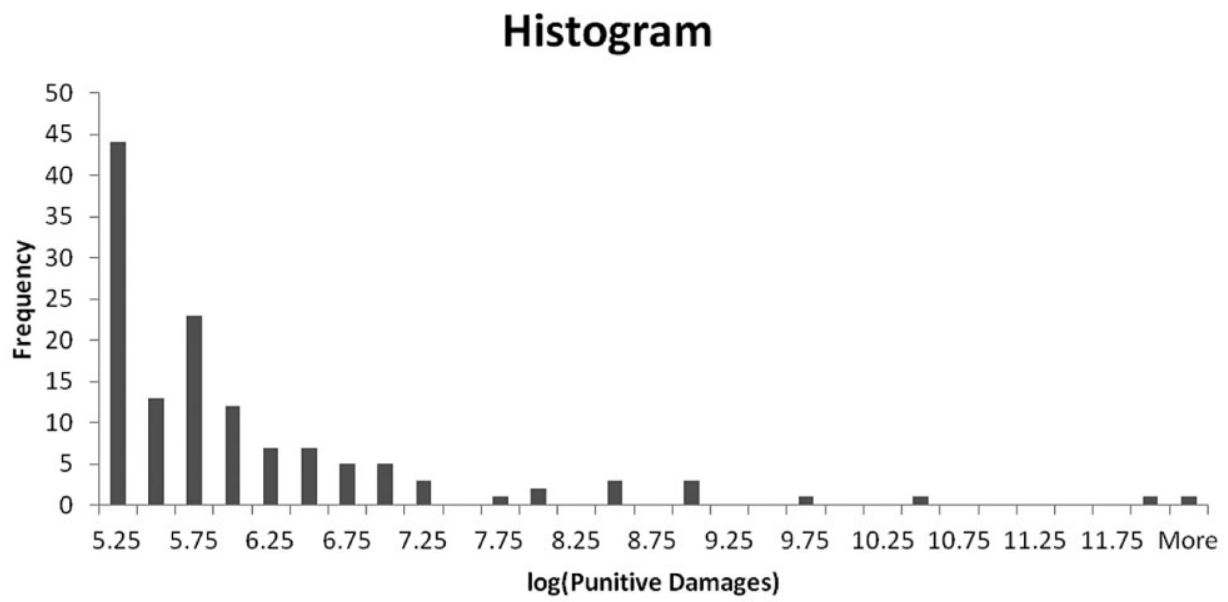

Figure 3 illustrates the right skew of blockbuster punitive damages awards, which are truncated at $\$ 100$ million. Even after taking the logarithm of award amounts, this skew is obvious and displays a fatter tail than would a lognormal distribution. The skewness for award levels is 7.9, while the skewness for the logarithms of awards is 2.4. These measures of skewness along with the figures demonstrate the positive skew of the distribution of blockbuster awards, meaning that the right tail of the distribution (which contains the large, outlying awards) is relatively longer than the left tail of the distribution. In terms of comparison, the skewness of a standard normal distribution is zero, indicating that the left and right tails of the distribution are essentially the same.

Figure 3 also illustrates the fat-tailed nature of blockbuster awards fairly well, as several of the intervals at the higher end of the distribution contain no awards, demonstrating that the largest awards are much larger than the next largest awards. To more accurately measure the thickness of the tails of the distribution of blockbuster punitive damages, we calculate excess kurtosis, which measures how heavy the tails of a distribution are. For the distribution of blockbuster punitive damages, the excess kurtosis is 63.5, and for the distribution of the logarithm of blockbuster punitive damages, the excess kurtosis is 7.2. Both measures indicate that the distribution has fat tails. The typical point of comparison for excess kurtosis is the standard normal, which has an excess kurtosis of zero. Because an excess kurtosis greater than zero indicates that a distribution has thick tails, the distribution of blockbuster punitive damages clearly has thick tails. ${ }^{20}$

\footnotetext{
${ }^{20}$ In terms of comparison to other common distributions, a logistic distribution with a zero mean, no skew, and a variance of 1 has an excess kurtosis of 1.2, and a uniform distribution with a zero mean and a variance of 1 has an excess kurtosis of -1.2 .
} 
Figure 4: Blockbuster punitive damages (PD) awards over time, 1981-2012.

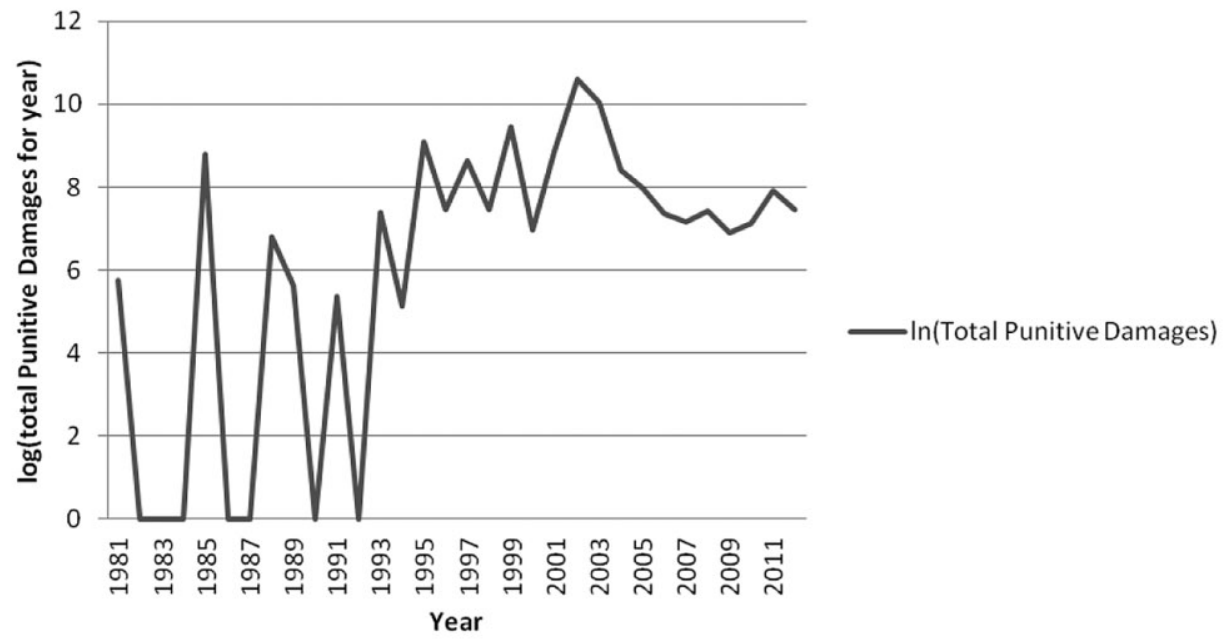

Figure 4 provides an overview of the annual total amount of blockbuster punitive damages that have been awarded. These awards were somewhat sporadic through the 1980s, producing a saw-tooth pattern of total punitive awards. In the 1990s, the total amount of punitive damages awarded as a result of blockbuster cases increased. Two important changes to the total amount of punitive damages awarded in terms of blockbuster awards occurred in the early 2000s. First, the total blockbuster award amount per year no longer increased but began to decline. Second, that decline occurred without much volatility. We analyze whether this somewhat dramatic decline was the result of the Supreme Court's decision in State Farm.

To begin that analysis, Figure 5 presents the "inverse" cumulative distribution function of blockbuster punitive damages awards before and after the State Farm decision. Both before and after State Farm, blockbuster awards follow a fat-tailed distribution. However, the distribution of awards shifted downward after the State Farm decision. After that decision, the awards are generally smaller. The pre-State Farm awards clearly follow a distribution with a fatter tail than that of the post-State Farm awards, suggesting that State Farm may have had a greater effect on the largest punitive damages awards. Considering only the four largest cases (Engle, ${ }^{21}$ Middleton v. Collins, ${ }^{22}$ Bullock v. Philip Morris, Inc.,${ }^{23}$ and Exxon Mobil Corporation

\footnotetext{
${ }^{21}$ Engle v. Liggett Group, Inc., 945 So. 2d 1246 (Fla. 2006). This citation is for the most recent version of this case, not the case in which the jury awarded the blockbuster amount. A jury originally imposed a blockbuster award in 2000. See Section IV for a more detailed discussion of Engle.
}

${ }^{22}$ The blockbuster award was originally imposed in 2011. See Top 100 Verdicts of 2011.

\footnotetext{
${ }^{23}$ Bullock v. Philip Morris USA, Inc., 198 Cal. App. 4th 543 (2011), rev. denied Nov. 30, 2011. This citation is for the most recent version of this case, not the case in which the jury awarded the blockbuster amount. A jury originally imposed a blockbuster award in 2002. See Section IV for a more detailed discussion of Bullock.
} 
Figure 5: Inverse cumulative distribution functions of blockbuster punitive damages awards.

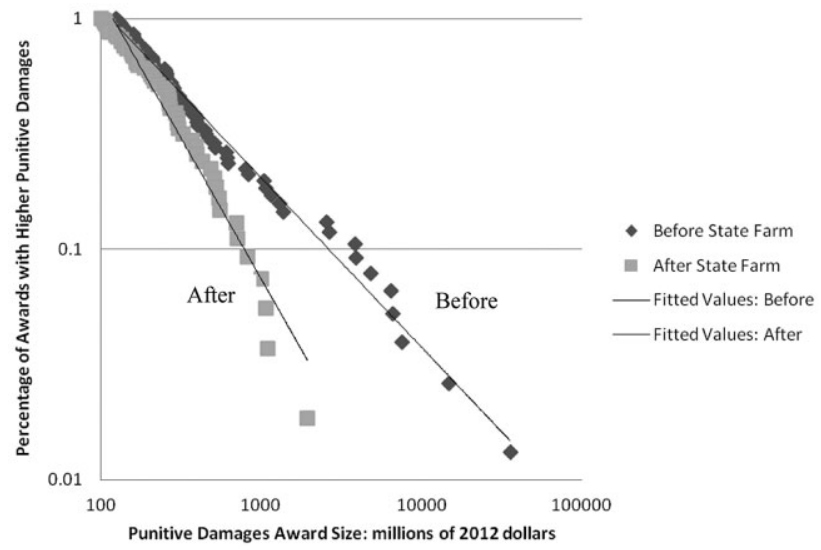

v. Alabama Department of Conservation and Natural Resources $\left.{ }^{24}\right)$, the greater number of outlying awards prior to State Farm (three of the four occurred prior to State Farm) suggests that lower courts became less willing to hand down extremely large judgments after State Farm. We discuss these four cases in greater detail below.

\section{B. Regression Analysis}

Turning to our regression analysis, we consider two primary questions. First, have individual award sizes decreased in the post-State Farm era and, second, has the single-digit ratio cap imposed by State Farm reduced the number of blockbuster cases with high (greater than 10) punitive to compensatory damages ratios? For both, we use the following general specification for the determinants of different measures, $Y_{i t}$, of punitive damages, which is an approach consistent with Del Rossi and Viscusi (2010):

$$
\begin{aligned}
& Y_{i t}=\alpha+\beta \log \left({\text { Compensatory Damages })_{i}}_{i} \delta \text { State } \text { Farm }_{i t}+\gamma \text { Litigant Type }_{i}+\text { OIndustry }_{i}+\varphi \text { State }_{i}\right. \\
& +\omega \text { Bench Trial }_{i}+\varepsilon_{i t} \text {, }
\end{aligned}
$$

where $i$ indexes individual cases and $t$ indexes time.

For the first analysis of the effect of State Farm on award size, $Y_{i t}$ is the natural logarithm of punitive damages, as is consistent with the Box-Cox analysis discussed above. ${ }^{25}$ For the second analysis concerning the effect of State Farm on the probability that an

\footnotetext{
${ }^{24}$ See Exxon Mobil Corp. v. Alabama Dep't of Conservation \& Natural Res., 986 So. 2d 1093, 1097-98 (Ala. 2007). The blockbuster award in this case was originally imposed in 2003.

${ }^{25}$ See Eisenberg et al. (2002), Hersch and Viscusi (2004), Del Rossi and Viscusi (2010), and Eisenberg and Heise (2011) for similar specifications.
} 
individual award violates the single-digit ratio, $Y_{i t}$ is an indicator for whether the punitive to compensatory damages ratio exceeds 10 . The explanatory variables include the natural logarithm of compensatory damages, and a higher level of compensatory damages is associated with a higher level of punitive damages in general. After State Farm, higher levels of compensatory damages should continue to be associated with higher levels of punitive damages, but an increase in compensatory damages should be associated with a smaller increase in punitive damages after State Farm than before. Because State Farm imposed a cap on the ratio between punitive and compensatory damages, the average and median ratios should decrease after that decision, which means that an additional dollar of compensatory damages should be, in general, worth fewer additional dollars of punitive damages after State Farm.

State Farm is an indicator for whether the case was heard after 2003 and is the principal variable of interest. This variable takes a value of 1 for every case heard in 2004 and thereafter. While the Supreme Court decided the State Farm case in April 2003, the State Farm indicator does not take a value of 1 until 2004 to allow for the decision to be fully implemented by lower courts. We use the State Farm indicator to test whether there was a shift in punitive damages award amounts after the Supreme Court handed down that decision. We also interact the State Farm indicator with the log of compensatory damages to determine if the relationship between compensatory and punitive damages changed after the State Farm decision, as one would predict based on the decision's guidance with respect to appropriate ratios of punitive damages to compensatory damages.

Litigant Type consists of a single indicator variable that controls for business and individual litigants, and the excluded category is other litigant types (governments, etc.). Industry is a vector of indicator variables for different industry types, including the automobile, tobacco, finance/investment/insurance, energy/chemical, and pharmaceutical/ health industries. This vector also includes an indicator for whether a case involved a violent crime. State is a vector including indicator variables for whether a case was decided in Texas or California-two states associated with large punitive awards. Finally, Bench Trial takes a value of 1 when a case was decided by a judge, not a jury.

In analyzing the effect of State Farm, we exclude several cases. First, we exclude Garamendiv. Altus Finance, S.A. and Chopourian v. Catholic Healthcare West from all regressions because the courts in these cases awarded no compensatory damages so that the ratio of punitive damages to compensatory damages for these cases is not defined. Second, we exclude both Middleton and Engle— the two largest cases—from some regressions. These two cases, as well as Bullock and Exxon Mobil, are discussed in greater detail in Section IV. ${ }^{26}$

Table 2 reports basic summary statistics for both logs and levels of punitive and compensatory damages as well as for all the variables used in the following regressions. In the sample of blockbuster awards, punitive damages are, on average, greater than compensatory damages. About 41 percent of blockbuster punitive damages awards were imposed after State Farm was decided. The energy/chemical industry, finance/investment/insurance

${ }^{26}$ We discuss these four cases because they are the four largest punitive damages awards ever imposed. They also illustrate the complexity of the litigation surrounding large punitive damages awards. 
Table 2: $\quad$ Summary Statistics ${ }^{\mathrm{a}}$

\begin{tabular}{lcc}
\hline Variables & Mean & SD \\
\hline Continuous Variables & & $2.171 \mathrm{e}+10$ \\
Punitive damages & $3.664 \mathrm{e}+09$ & $1.619 \mathrm{e}+09$ \\
Compensatory damages & $3.301 \mathrm{e}+08$ & 1.319 \\
$\log$ (Punitive damages) & 19.75 & 2.051 \\
$\log$ (Compensatory damages) & 17.39 & 0.493 \\
Indicator Variables & & 0.291 \\
State Farm & 0.408 & 0.211 \\
Automobile industry & 0.092 & 0.389 \\
Tobacco industry & 0.046 & 0.413 \\
Finance, investment, insurance industry & 0.185 & 0.402 \\
Energy, chemical industry & 0.215 & 0.211 \\
Pharmaceuticals, health industry & 0.200 & 0.492 \\
Violent crime & 0.046 & 0.407 \\
Business and individual litigants & 0.600 & 0.396 \\
Texas & 0.208 & 0.211 \\
California & 0.192 & 0.046 \\
\hline
\end{tabular}

${ }^{\text {aAll }}$ awards are in 2012 dollars. All statistics exclude the Garamendi and Chopourian cases, which involved no compensatory damages. $N=130$.

industry, and the health/pharmaceutical industry were each involved in about 20 percent of cases in which a blockbuster award was imposed, while no other industry accounted for more than 10 percent of blockbuster awards. Collectively, Texas and California courts awarded about 40 percent of all blockbuster awards. Interestingly, judges were responsible for less than 5 percent of blockbuster awards.

Before moving to our regression analysis, Figure 6 plots the logarithm of compensatory damages against the logarithm of punitive damages to illustrate how State Farm affected blockbuster punitive damages awards. In addition to showing the relationship between compensatory and punitive damages both before and after State Farm, Figure 6 demonstrates the drop in punitive damages award amounts following State Farm. Although the slope of the line capturing the relationship between compensatory and punitive damages decreases slightly after State Farm, the drop in award amounts, illustrated by the distance between the lines, is obvious.

Table 3 reports four sets of OLS regression results for the log of punitive damages. The first column reports a simple regression with only two regressors relating to the relationship between compensatory and punitive damages and the effect of State Farm. The results indicate that after State Farm, punitive damages decreased by about 45 percent. ${ }^{27}$ Here, and throughout our regression analysis, we report robust standard errors as well as bootstrapped standard errors to address potential concerns about small cell counts. The

\footnotetext{
${ }^{27}$ Because this model involves a semi-logarithmic equation, the interpretation of the coefficients on indicator variables is not straightforward. Any indicator coefficient must be transformed using the basic formula $\exp (\beta)-1$, where $\beta$ is the estimated coefficient, to determine the marginal effect of the relevant variable (Halvorsen \& Palmquist 1980).
} 
Figure 6: Scatterplot of awards before and after State Farm.

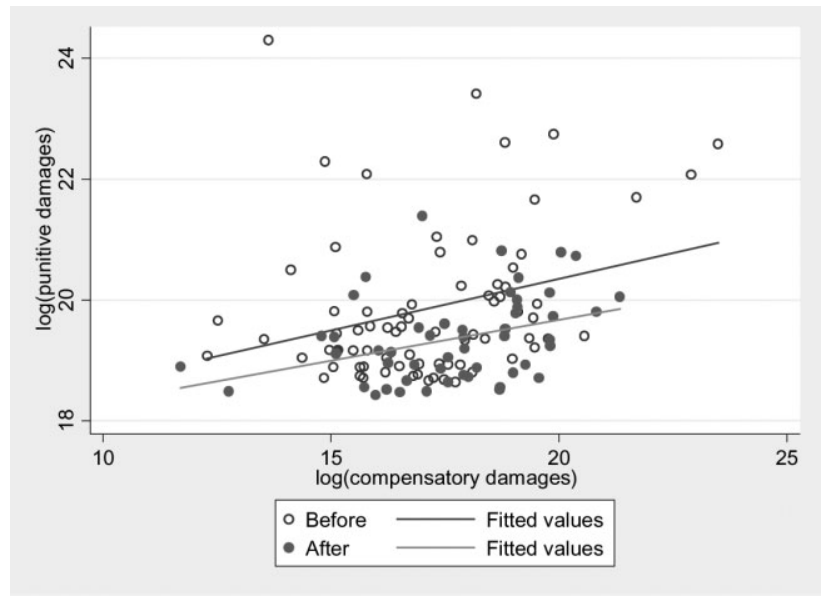

second column reports a simple regression with both regressors relating to the relationship between compensatory and punitive damages. These results indicate that this relationship shifted after the Supreme Court decided State Farm. Because both the dependent and independent variables are in log form, the coefficient on the log of compensatory damages can be interpreted as an elasticity. Prior to State Farm, a 10 percent increase in compensatory damages is associated with a 1.70 percent increase in punitive damages. The coefficient on the interaction between the log of compensatory damages and the State Farm indicator represents how that elasticity changed after the State Farm decision. The magnitude of the elasticity decreased by 0.034 after State Farm, leading to a net elasticity of about 0.14. Interestingly, the results for the interaction term are consistent with those of Del Rossi and Viscusi (2010), indicating that the effect of State Farm has been relatively stable over time.

The third column of Table 3 includes both an indicator for State Farm and an interaction between the State Farm indicator and the logarithm of compensatory damages. Neither is statistically significant. The two State Farm coefficients are, however, jointly significant. ${ }^{28}$ Subsequent discussion will focus on the simpler intercept shift formulation of the State Farm effect. The final column of Table 3 reports results for a regression adding the full array of controls discussed above. The statistically significant coefficient on the State Farm indicator in this column demonstrates that the effect of State Farm survives even after controlling for other factors that affect punitive damages. However, the magnitude of the State Farm effect does decrease from 45 percent to about 41 percent in the regression with all the control variables included.

We repeated the regressions reported in Table 3 with an indicator variable for whether a case was decided after Exxon Shipping Co. v. Baker. In that case, the U.S. Supreme

\footnotetext{
${ }^{28}$ We calculate an $F$ statistic of 6.54 , indicating the two variables are jointly significant.
} 
Table 3: OLS Regression Results of Log (Punitive Damages) ${ }^{\mathrm{a}}$

\begin{tabular}{|c|c|c|c|c|}
\hline Variables & (1) & (2) & (3) & (4) \\
\hline \multirow[t]{3}{*}{$\log$ (Compensatory damages) } & 0.158 & 0.170 & 0.171 & 0.194 \\
\hline & $(0.054) * * *$ & $(0.055) * * *$ & $(0.081)^{* *}$ & $(0.052) * * *$ \\
\hline & {$[0.056] * * *$} & {$[0.065] * * *$} & {$[0.078]^{* *}$} & {$[0.055] * * *$} \\
\hline \multirow[t]{3}{*}{ State Farm } & -0.592 & & 0.029 & -0.533 \\
\hline & $(0.164) * * *$ & & $(1.577)$ & $(0.167)^{* * *}$ \\
\hline & {$[0.159] * * *$} & & {$[1.528]$} & {$[0.182] * * *$} \\
\hline \multirow[t]{3}{*}{$\log ($ Compensatory damages $) \times$ State Farm } & & -0.034 & -0.035 & \\
\hline & & $(0.009)^{* * *}$ & $(0.090)$ & \\
\hline & & {$[0.010] * * *$} & {$[0.088]$} & \\
\hline \multirow[t]{3}{*}{ Business and individual litigants } & & & & 0.395 \\
\hline & & & & $(0.199)^{* *}$ \\
\hline & & & & {$[0.180]^{* *}$} \\
\hline \multirow[t]{3}{*}{ Automobile industry } & & & & 0.087 \\
\hline & & & & $(0.290)$ \\
\hline & & & & {$[0.292]$} \\
\hline \multirow[t]{3}{*}{ Tobacco industry } & & & & 2.030 \\
\hline & & & & $(0.871)^{* *}$ \\
\hline & & & & {$[0.971]^{* *}$} \\
\hline \multirow[t]{3}{*}{ Finance, investment, insurance industry } & & & & 0.660 \\
\hline & & & & {$[0.191]^{* * *}$} \\
\hline & & & & $(0.191)^{* * *}$ \\
\hline \multirow{3}{*}{ Energy, chemical industry } & & & & 0.754 \\
\hline & & & & $(0.250)^{* * *}$ \\
\hline & & & & {$[0.249] * * *$} \\
\hline \multirow[t]{3}{*}{ Pharmaceuticals, health industry } & & & & 0.552 \\
\hline & & & & $(0.207)^{* * *}$ \\
\hline & & & & {$[0.202] * * *$} \\
\hline \multirow[t]{3}{*}{ Violent crime } & & & & 0.699 \\
\hline & & & & $(0.255)^{* * *}$ \\
\hline & & & & {$[0.294] * *$} \\
\hline \multirow[t]{3}{*}{ Texas } & & & & -0.296 \\
\hline & & & & $(0.214)$ \\
\hline & & & & {$[0.218]$} \\
\hline \multirow[t]{3}{*}{ California } & & & & 0.195 \\
\hline & & & & $(0.236)$ \\
\hline & & & & {$[0.257]$} \\
\hline \multirow[t]{3}{*}{ Bench trial } & & & & 0.109 \\
\hline & & & & $(0.294)$ \\
\hline & & & & {$[0.344]$} \\
\hline \multirow[t]{3}{*}{ Constant } & 17.154 & 16.945 & 16.935 & 15.760 \\
\hline & $(0.951)^{* * *}$ & $(0.951) * * *$ & $(1.412) * * *$ & $(0.979)^{* * *}$ \\
\hline & {$[0.969] * * *$} & {$[1.121] * * *$} & {$[1.342] * * *$} & {$[1.007] * * *$} \\
\hline$R^{2}$ & 0.141 & 0.142 & 0.142 & 0.338 \\
\hline
\end{tabular}

${ }^{a}$ The dependent variable is the natural $\log$ of punitive damages in all specifications. All awards are in 2012 dollars. The excluded industry category is other industry. All specifications exclude the Garamendi and Chopourian cases, which involved no compensatory damages, and the Engle and Middleton cases, which involved the two largest PD awards in the data set. Robust standard errors are in parentheses, and bootstrapped standard errors are in brackets. $N=128$. ***Significant at $1 \%$ level; **significant at $5 \%$ level; *significant at $10 \%$ level. 
Court limited the punitive to compensatory damages ratio to 1 under federal maritime law. While that decision does not apply to cases generally, Justice Ginsburg indicated in her opinion that the Court favored stricter limitations on punitive damages. Therefore, we included this case in our analysis to examine whether State Farm is the driving force behind any observed change in blockbuster awards. Neither the coefficient on the indicator for Baker nor the coefficient on the interaction between the indicator for Baker and the log of compensatory damages was ever statistically significant, and none of the other results changed in any meaningful way.

Because blockbuster awards follow a fat-tailed distribution, as opposed to a normal or lognormal distribution, we also estimate quantile regression models, which are better suited to analyzing the effects of State Farm across the distribution of awards. The number of variables that can be used in a quantile regression is limited, especially with a small sample size, because these regressions concentrate on the determinants of award amounts for specific quantiles accounting for the probability of being in a given quantile. Therefore, we do not include all the control variables we use in the OLS regressions.

Table 4 reports a series of quantile regression results for the 25th, 50th, and 75th percentiles. Because quantile regressions are robust to large outliers, we do not exclude any large awards from this analysis; however, because the award in the Engle cigarette class action case dwarfed all other awards up to that time, all the regressions in Table 4 control for the effect Engle may have had on the relationship between compensatory and punitive damages. Again, we estimate our regressions using both robust and bootstrapped standard errors. Consistent with the OLS regression results, the State Farm decision has a significant

Table 4: Quantile Regression Results

\begin{tabular}{|c|c|c|c|}
\hline Variables & $\begin{array}{l}(1) \\
25 t h\end{array}$ & $\begin{array}{c}(2) \\
\text { Median }\end{array}$ & $\begin{array}{l}(3) \\
75 t h\end{array}$ \\
\hline $\begin{array}{l}\log (\text { Compensatory } \\
\text { damages })\end{array}$ & $\begin{array}{l}0.101 \\
(0.023)^{* * *} \\
{[0.044]^{* *}}\end{array}$ & $\begin{array}{l}0.153 \\
(0.033)^{* * * *} \\
{[0.048]^{* * * *}}\end{array}$ & $\begin{array}{l}0.179 \\
(0.063)^{* * * *} \\
{[0.061]^{* * *}}\end{array}$ \\
\hline State Farm & $\begin{array}{l}-0.518 \\
(0.175)^{* * * *} \\
{[0.312]^{*}}\end{array}$ & $\begin{array}{l}-0.553 \\
(0.192) * * * \\
{[0.385]}\end{array}$ & $\begin{array}{l}-1.401 \\
(0.296)^{* * * *} \\
{[0.598]^{* *}}\end{array}$ \\
\hline Engle & $\begin{array}{c}-0.261 \\
(0.175) \\
{[0.309]}\end{array}$ & $\begin{array}{l}-0.347 \\
(0.191) * \\
{[0.383]}\end{array}$ & $\begin{array}{l}-1.056 \\
(0.302) * * * \\
{[0.648]}\end{array}$ \\
\hline Constant & $\begin{array}{l}17.493 \\
(0.423)^{* * * *} \\
{[0.827]^{* * *}}\end{array}$ & $\begin{array}{l}17.191 \\
(0.589) * * * \\
{[0.869] * * *}\end{array}$ & $\begin{array}{l}17.981 \\
(1.161)^{* * * *} \\
{[1.359]^{* * *}}\end{array}$ \\
\hline
\end{tabular}

aAll columns report the quantile regression at the percentile noted in the column heading. The dependent variable is the natural $\log$ of punitive damages in all specifications. All specifications exclude the Garamendi and Chopourian cases, which involved no compensatory damages. Robust standard errors are in parentheses, and bootstrapped standard errors are in brackets. $N=130$.

***Significant at $1 \%$ level; **significant at $5 \%$ level; *significant at $10 \%$ level. 
negative effect on the punitive damages for each of the quantiles. The State Farm indicator is significant in all regressions except for the median regression with bootstrapped standard errors (it is significant when robust standard errors are used). This significance implies that State Farm is associated with a negative shift in punitive damages awards.

The pattern of the coefficients for the State Farm effect is especially interesting. Looking at the magnitudes of the State Farm effect across the three sets of estimates, the State Farm decision influenced awards at the higher end of the distribution more substantially than those at the lower end. The coefficient has similar values of -0.518 for the 25th percentile and -0.553 for the median. However, the coefficient more than doubles in absolute value to -1.401 for the 75 th percentile, indicating that State Farm has had the biggest impact on the most extreme awards.

The combined evidence from the OLS and quantile regressions demonstrates that the State Farm decision changed how punitive damages in blockbuster cases are awarded. The evidence from the regressions is consistent with Figure 5, which plots power function trend lines for awards imposed before and after the State Farm decision. These trend lines in Figure 5 demonstrate visually that while blockbuster punitive damages awards still follow a power-law distribution after State Farm, award levels have been lower since 2004. Consistent with the results of the quantile regressions, Figure 5 also demonstrates that the effect of State Farm has been strongest for the larger awards, as the power-law trend line for the awards after State Farm decreases more quickly than the trend line for the awards before State Farm. Overall, State Farm shifted the inverse cumulative distribution function of blockbuster cases down. ${ }^{29}$ Similar to other figures and tables, the trend lines plotted in Figure 5 exclude the two largest cases, while the quantile regressions do not.

To more accurately capture the evidence demonstrated visually by Figure 5, we calculate the skewness and excess kurtosis of the distributions of blockbuster punitive damages awards before and after State Farm was decided. The distribution of pre-State Farm blockbuster awards has an excess kurtosis of 70.6, and this decreases to 55 for the distribution of post-State Farm awards, indicating that the post-State Farm distribution has a thinner tail than the pre-State Farm distribution. The skewness of the distributions of pre- and post-State Farm award amounts follows a similar pattern. The distribution of pre-State Farm awards has a skewness of 8.3 , and this decreases to 7.4 for the distribution of post-State Farm awards, indicating that the post-State Farm distribution is less skewed than the pre-State Farm distribution.

Excluding the largest case from both the pre- and post-State Farm distributions (Engle and Middleton, respectively) makes the differences between the two distributions even more dramatic. The excess kurtosis of the pre-State Farm distribution is 44.6, and this decreases to 9.7 for the post-State Farm distribution. The skewness of the pre-State Farm distribution is 6.3, while the skewness of the post-State Farm distribution is 2.8. These measures of excess

\footnotetext{
${ }^{29}$ To confirm that the shift observed in the inverse cumulative distribution function represents a statistically significant change in the power-law function that describes the cases before and after State Farm, we ranked the cases before and after State Farm so that the following power-law function describes them: award rank $=(\text { award size })^{\beta}$. The exponent $\beta$ that characterizes the power-law relationship is significantly different for awards imposed before and after State Farm $(t$ statistic $=22.67)$.
} 
Table 5: Generalized Extreme Value

Distribution Results ${ }^{\mathrm{a}}$

\begin{tabular}{lccc}
\hline & $(4)$ & $(5)$ & $(6)$ \\
& Scale & Shape & Location \\
\hline \multirow{2}{*}{ State Farm } & $-4.686 \mathrm{e}+07$ & -0.404 & $-4.115 \mathrm{e}+07^{*}$ \\
& $(3.895 \mathrm{e}+07)$ & $(0.298)$ & $(2.387 \mathrm{e}+07)$ \\
Constant & $1.413 \mathrm{e}+08^{* * *}$ & $1.538^{* * *}$ & $2.091 \mathrm{e}+08^{* * *}$ \\
& $(3.264 \mathrm{e}+07)$ & $(0.200)$ & $(1.831 \mathrm{e}+07)$ \\
\hline
\end{tabular}

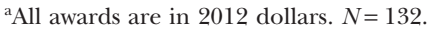

***Significant at $1 \%$ level; **significant at $5 \%$ level; *significant at $10 \%$ level.

kurtosis and skewness indicate that while the distributions of blockbuster awards before and after State Farm have thick tails and positive skews, the tail becomes thinner and the skew less dramatic after State Farm. This evidence is consistent with the results of our regression analysis indicating that State Farm is associated with a decrease in blockbuster award amounts.

In addition to calculating skewness and kurtosis to capture a general sense of the distribution of blockbuster punitive damages awards, we also fit a generalized extreme value distribution to our sample using a maximum likelihood approach. ${ }^{30}$ The generalized extreme value distribution is used to model extreme or rare events and is characterized by three parameters: scale, shape, and location. ${ }^{31}$ The scale parameter captures how spread out the distribution is ${ }^{32}$ and the shape parameter captures the form of the distribution, for example, the peak of the distribution. The location parameter captures where the distribution falls, and a change in this parameter indicates a lateral shift of the distribution without affecting its shape or spread.

In Table 5, we fit a generalized extreme value distribution to our data on blockbuster punitive damages awards and estimate the effect State Farm has had on all three of the distribution's parameters. State Farm did not have a statistically significant effect on either the scale or shape parameters, but it did have a significant and negative effect on the location of the distribution. This effect indicates that State Farm caused a left (negative) shift in the location of the distribution. In other words, while the distribution of blockbuster awards looks similar before and after State Farm, it is centered around smaller awards.

The evidence from the regressions, the visual evidence from Figure 5, and the evidence from the generalized extreme value distribution fitting in Table 5 indicate that

\footnotetext{
${ }^{30}$ Previous work noted but did not utilize statistical methods to address the extreme value nature of punitive damages. See, for example, Eisenberg and Wells (2006:181 n13).

${ }^{31}$ For a more complete treatment of the generalized extreme value distribution, see Kotz and Nadarajah (2000).

${ }^{32} \mathrm{~A}$ change in the scale parameter indicates a stretching or shrinking of the distribution.
} 
State Farm has significantly influenced how lower courts impose punitive damages. While we do not have data on the mechanism through which State Farm has affected blockbuster awards, several scenarios are possible. ${ }^{33}$ First, juries may have decreased the awards they impose after the Supreme Court decided State Farm. However, it is very unlikely that most juries know that State Farm exists or know how it limited punitive damages awards, making it unlikely that the State Farm decision is acting directly through juries. Second, judges, who do know about State Farm, may have decreased the awards they impose. However, given that judges were responsible for less than 5 percent of blockbuster awards, this potential mechanism is implausible. The most likely scenario concerns attorneys. They know about State Farm and could have changed the amount of punitive damages they demanded or altered their litigation strategies in some way in response to its holding. They may have changed their demands or strategies based on a desire to avoid the appeals process for a punitive damages award that would almost certainly be overturned based on State Farm.

Although the mechanism through which State Farm affects awards is not entirely clear, the evidence on award amounts demonstrates a State Farm effect. However, this evidence elucidates State Farm's effect on blockbuster punitive damages awards generally. Because State Farm imposed a single-digit cap on the ratio between punitive and compensatory damages, it is important to determine if the observed State Farm effect influences punitive damages awards in general or is concentrated around the single-digit threshold. Therefore, we conclude our empirical analysis of the State Farm effect by directly testing whether lower courts are more likely to impose awards with single-digit punitive to compensatory damages ratios after State Farm.

Prior to the State Farm decision, federal and state courts imposed a total of 77 blockbuster punitive damages awards. Of these awards, 43 (or 56 percent) involved a double-digit ratio of punitive to compensatory damages. Since the U.S. Supreme Court decided State Farm, federal and state courts have imposed a total of 55 blockbuster awards. ${ }^{34}$ Of these awards, 16 (or 29 percent) involved a double-digit ratio of punitive to compensatory damages. ${ }^{35}$ The decrease in the percentage of blockbuster awards exceeding the single-digit ratio imposed by State Farm suggests that State Farm may have changed how lower courts impose punitive damages awards, and we use probit models to examine this potential change more closely.

Table 6 reports the results from three probit regressions in which the dependent variable is an indicator for whether the punitive to compensatory damages ratio in a case

\footnotetext{
${ }^{33}$ Because we lack the relevant data, we cannot confirm that any particular scenario is true. We also do not claim that the scenarios presented here are an exhaustive list of the potential mechanisms through which State Farm is acting on blockbuster awards.

${ }^{34}$ Two of these awards involved no accompanying compensatory damages award. We drop these cases in our analysis of ratio of punitive to compensatory damages.

${ }^{35}$ Including the cases that involved an undefined punitive to compensatory damages ratio increases this number to 18 (33 percent).
} 
Table 6: Probit Regressions for Whether Awards Violated the Single-Digit Ratio Cap ${ }^{a}$

\begin{tabular}{|c|c|c|c|}
\hline Variables & (1) & (2) & (3) \\
\hline $\log$ (Compensatory damages $)$ & $\begin{array}{l}-0.397 \\
(0.070) * * * \\
{[0.137]^{* * *} *}\end{array}$ & $\begin{array}{l}-0.391 \\
(0.069) * * * \\
{[0.096]^{* * * *}}\end{array}$ & $\begin{array}{l}-0.511 \\
(0.102) * * * \\
{[0.102] * * *}\end{array}$ \\
\hline State Farm & $\begin{array}{l}-0.320 \\
(0.099) * * * \\
{[0.134] * *}\end{array}$ & & $\begin{array}{l}-0.306 \\
(0.141)^{* *} \\
{[0.141]^{* *}}\end{array}$ \\
\hline $\log ($ Compensatory damages $) \times$ State Farm & & $\begin{array}{l}-0.021 \\
(0.007)^{* * * *} \\
{[0.007]^{* * *}}\end{array}$ & \\
\hline Business and individual litigants & & & $\begin{array}{c}0.134 \\
(0.176) \\
{[0.176]}\end{array}$ \\
\hline Automobile industry & & & $\begin{array}{c}0.170 \\
(0.305) \\
{[0.305]}\end{array}$ \\
\hline Tobacco industry & & & $\begin{array}{c}-0.090 \\
(0.176) \\
{[0.176]}\end{array}$ \\
\hline Finance, investment, insurance industry & & & $\begin{array}{l}0.504 \\
(0.153)^{* * *} \\
{[0.153]^{* * *}}\end{array}$ \\
\hline Energy, chemical industry & & & $\begin{array}{l}0.584 \\
(0.144)^{* * *} \\
{[0.144]^{* * *}}\end{array}$ \\
\hline Pharmaceuticals, health industry & & & $\begin{array}{c}0.289 \\
(0.195) \\
{[0.195]}\end{array}$ \\
\hline Violent crime & & & $\begin{array}{c}0.015 \\
(0.271) \\
{[0.271]}\end{array}$ \\
\hline Texas & & & $\begin{array}{l}-0.409 \\
(0.103)^{* * *} \\
{[0.103]^{* * *}}\end{array}$ \\
\hline California & & & $\begin{array}{c}0.368 \\
(0.204)^{*} \\
{[0.204]^{*}}\end{array}$ \\
\hline Bench trial & & & $\begin{array}{c}0.033 \\
(0.272) \\
{[0.272]}\end{array}$ \\
\hline
\end{tabular}

${ }^{a}$ All columns report marginal effects of probit models. Dependent variable is an indicator for whether the PD to CD ratio exceeded 10. Excluded industry category is other industry. All specifications exclude the Garamendi and Chopourian cases, which involved no compensatory damages, and the Engle and Middleton awards. Robust standard errors are in parentheses, and bootstrapped standard errors are in brackets. $N=128$.

***Significant at $1 \%$ level; **significant at $5 \%$ level; *significant at $10 \%$ level. 
exceeded $10 .{ }^{36}$ All coefficients have been transformed to correspond to marginal effects. In all three columns, the coefficient on the log of compensatory damages is negative, indicating that for higher levels of compensatory damages, the total award in a case is less likely to violate the single-digit ratio cap. The first column reports a simple regression with an indicator for State Farm, and the coefficient on that term is negative and significant. After State Farm, the probability of exceeding the single-digit ratio decreased by 32 percentage points. Since the raw probability of exceeding the single-digit ratio prior to State Farm was about 0.56 , a decrease of 0.32 attributable to State Farm represents a substantial decrease.

In the second column of Table 6, the coefficient on the State Farm interaction term is negative and significant, so the State Farm decision changed how courts award punitive damages in relation to compensatory damages. For a given level of compensatory damages, after the Court decided State Farm, lower courts became less likely to impose an award in which the punitive to compensatory damages ratio exceeded 10 .

The third column of Table 6 reports results for a regression with the full array of controls. Here, State Farm has a negative and significant effect. Interestingly, even after including additional controls, the magnitude of that effect decreases by less than 0.02 relative to the first column, which included no other control variables. This suggests that State Farm was responsible for a 30 percentage point decrease in the probability of crossing the single-digit ratio threshold. This represents a more than 50 percent decrease in the probability of exceeding the cap considering the raw probability prior to State Farm was 0.56.

\section{The Four Largest Blockbuster Punitive Damages Cases}

Our analysis indicates that State Farm had a broader effect than simply decreasing the probability of crossing the double-digit threshold. However, that analysis has considered only the award imposed on the defendant and not what the defendant ultimately paid to the plaintiff. In practice, defendants may not pay the full award amount for a variety of reasons, including postverdict settlements, reduction of the award through remittitur, or reduction of the award by a higher court. In this section, we discuss the four largest blockbuster punitive damages awards ever imposed to illustrate the postverdict litigation processes that may reduce the amount the defendant must ultimately pay in a given case.

Viscusi (2004) discusses why defendants may not ultimately pay the full award amount and provides additional information on the litigation history of 64 blockbuster awards. Of those 64 awards, 10 were reversed on appeal while only one was affirmed on appeal. One case required a retrial, while three awards were reduced on appeal, and three more settled

\footnotetext{
${ }^{36}$ The Court in State Farm actually said that "few awards exceeding a single-digit ratio between punitive and compensatory damages, to a significant degree, will satisfy due process." 538 U.S. at 425 . However, we use an indicator for whether a given ratio exceeds 10 because clever attorneys may point out that $9.999 \ldots=10$ and that $9.999 \ldots$ is still a single digit. This formulation of the indicator variable allows for the widest possible interpretation of the Supreme Court's ruling. Only two cases involved a ratio of exactly 10.
} 
during the appellate process. One award was reduced by the trial court, and 21 cases settled prior to the appellate process. In two cases, the defendant did not pay the punitive damages award.

The discussion here concerns only four cases, but it provides much greater detail on the litigation parties engage in after a court imposes a blockbuster punitive damages award. Unlike earlier work that provided only the postaward outcome of a case, this discussion illuminates the litigation histories of the four largest cases to illustrate not only that defendants may not ultimately pay the initial blockbuster award, but also the complexity and length of the litigation involved in these types of cases.

State courts imposed all four of the most extreme awards, and three were imposed prior to State Farm while one was awarded after. Only one of these awards survived subsequent litigation, but it is highly unlikely that even in that case the defendant will pay the full award. Because each case was quite complex-one case involved over 57,000 pages of litigation transcripts- the discussion here is necessarily a succinct overview.

\section{A. Engle v. R.J. Reynolds Tobacco}

Beginning with what may be the most widely discussed punitive damages case, a Florida circuit court decided Engle v. R.J. Reynolds Tobacco in 2000 (prior to State Farm), awarding $\$ 144.8$ billion in punitive damages. This award remains the largest (after adjusting for inflation) punitive damages award in history. Coupled with an initial compensatory damages award of $\$ 12.7$ million, this case involved a punitive to compensatory damages ratio of over $11,000 .{ }^{37}$ Here, we explore the process that generated this award as well as why this award was never paid. The case began in 1994 as a class action lawsuit on behalf of all U.S. citizens injured by addiction to cigarettes. The plaintiffs alleged that the tobacco industry intentionally manipulated the nicotine in cigarettes to make them more addictive and concealed information concerning these actions and the addictive nature of nicotine in cigarettes. A Florida appellate court reduced the class certification to only Floridians harmed by cigarettes and held that while liability could be determined on a class basis, damages should be determined individually. After the class was certified, the trial court conceived a trial plan involving three phases to handle a class of more than 500,000 individuals.

In Phase I, a jury of six found R.J. Reynolds and other tobacco companies liable for a number of alleged harms (many of which involved some sort of fraud) and determined that punitive damages were allowable without setting a specific amount of either compensatory or punitive damages. Phase II involved the determination of compensatory damages for two representative class members and the assessment of a lump sum of punitive damages for the entire class. When the trial court announced it would impose punitive damages as a lump sum prior to determining individual damages for each class member, the tobacco companies appealed the use of this procedure, but the Florida Supreme Court allowed the trial court to use this procedure while allowing the tobacco companies to appeal this issue

\footnotetext{
${ }^{37}$ This ratio is somewhat misleading, as the compensatory damages award was for a few representative class members while the punitive damages award was for the entire class.
} 
again in future litigation. Imposing punitive damages as a lump sum for the entire class, the jury arrived at a total award of $\$ 144.8$ billion. ${ }^{38}$ The size of the punitive damages award and the novel procedures that led to its imposition prompted action by the state legislature and state attorney general. The legislature passed a law preventing large punitive damages awards (such as the one in Engle) from being paid out while a case proceeded through the appeals process. The attorney general entered the appeals process on the side of the tobacco companies, arguing that the procedure used by the trial court to impose the large punitive award violated state law and that the size of the award violated the Due Process Clause of the Fourteenth Amendment.

The Florida District Court of Appeal issued an opinion in 2003 that was favorable to the tobacco companies. ${ }^{39}$ The court held that the class of smokers in the case was not properly certified and struck down the punitive damages award on several grounds. First, the court held that awarding punitive damages for the entire class without additional evidence being presented was improper. Second, even if the punitive damages award had been properly determined, it was excessive under both state and federal law. The court explained that a punitive award could not be so large as to bankrupt/destroy a defendant under Florida law and, citing State Farm, held that such a large award violated the Due Process Clause. Finally, the court explained that when setting the punitive damages award in Engle, the trial court had erred in not considering the Florida Settlement Agreement, which assessed punitive damages against tobacco companies on behalf of the citizens of Florida.

The Supreme Court of Florida held that the Florida Settlement Agreement did not prohibit the trial court from awarding punitive damages, but it did uphold the appellate court's ruling overturning the punitive damages award. The court explained that while a lower court need not award a specific amount of compensatory damages prior to determining whether the plaintiff is entitled to punitive damages, it must fully consider all aspects of liability prior to determining that punitive damages are allowable. In this case, the jury did not do so. Additionally, the court held that before setting a specific amount of punitive damages, lower courts must set a specific amount of compensatory damages because they must consider whether the punitive award is reasonably related to the harm caused (as reflected by the total compensatory award). Here, the jury did not know the total compensatory award before determining the total punitive award, which violated both state and federal law. The court cited State Farm in striking down the lower court's procedure of determining punitive damages prior to knowing the total harm caused and held for the first time under Florida law that the punitive award must bear a reasonable relationship to the compensatory award. Ultimately, the court was more favorably disposed toward the plaintiffs than the appellate court but upheld the ruling striking down the punitive award.

\footnotetext{
${ }^{38}$ Individual class members were supposed to receive an equal portion of the lump punitive damages award regardless of their individual compensatory award.

${ }^{39}$ Liggett Group, Inc. v. Engle, 853 So. $2 d 434$ (Fla. Dist. Ct. App. 2003), decision approved in part, quashed in part sub nom. Engle v. Liggett Group, Inc., 945 So. 2d 1246 (Fla. 2006).
} 
The Supreme Court of Florida affirmed the ruling striking down the blockbuster award, but the litigation surrounding Engle continued. A full review of the Engle "progeny cases" is well beyond the scope of this work, but Henderson and Twerski (2010) provide a thorough discussion of tobacco litigation, including the cases spawned by Engle, though from a plaintiff-oriented perspective.

\section{B. Bullock v. Philip Morris USA}

Unlike the award in Engle, the punitive damages award in Bullock v. Philip Morris USA survived the appeals process, albeit at a lower level than initially awarded. ${ }^{40}$ In this case, a single plaintiff filed a suit against Philip Morris for lost earnings and medical expenses stemming from the plaintiff's smoking. In 2002 (prior to State Farm), the jury awarded $\$ 850,000$ in compensatory damages and $\$ 28$ billion in punitive damages, resulting in a punitive to compensatory damages ratio of nearly 33,000. After the defendant challenged the punitive award, the court, relying on the U.S. Supreme Court's decision in BMWv. Gore, determined that the punitive award was legally excessive. The court offered the plaintiff a choice: accept either a new trial or a reduction of the punitive damages award to $\$ 28$ million, which reduced the punitive award by a factor of 1,000. The plaintiff accepted the reduced award, and both the plaintiff and defendant appealed the trial court's ruling.

The appellate court rejected Philip Morris's arguments that the reduced award was unreasonable under State Farm (which was decided between the trial and appellate proceedings in this litigation) and upheld the $\$ 28$ million award. Philip Morris appealed to the California Supreme Court, but that court deferred hearing the case until the Supreme Court of the United States decided Philip Morris USA v. Williams, ${ }^{41}$ which was expected to provide guidance on some of the issues in the Bullock litigation. After the Court decided Williams, holding that a punitive damages award could not punish the defendant for harms to individuals outside the scope of the current litigation, the California Supreme Court transferred the Bullock case back to the appellate court for reconsideration. There, the court of appeal rejected Philip Morris's indirect challenges to the punitive award (e.g., evidentiary challenges) and its direct challenges to the trial court's findings. However, the court ordered a new trial on the issue of punitive damages because the jury instructions used in the original trial were not consistent with the Supreme Court's holding in Williams. The jury instructions did not adequately explain to the jury that any punitive award could not punish the defendant for harms inflicted on parties outside the litigation.

At the new trial, the jury awarded the plaintiff $\$ 13.8$ million in punitive damages. Philip Morris appealed this award, but the court of appeal upheld the award and rejected Philip Morris's arguments after a thorough analysis of the reasonableness of a punitive damages award under State Farm and state court decisions. Interestingly, the appellate court

\footnotetext{
${ }^{40}$ This case changed names throughout the litigation. Bullock v. Morris, BC249171, 2002 WL 31833905 (Cal. App. Dep't Super. Ct. Dec. 18, 2002), aff'd sub nom. Bullock v. Philip Morris USA, Inc., 138 Cal. App. 4th 1029, 42 Cal. Rptr. 3d 140 (2006), review granted and opinion superseded, 141 P.3d 718 (Cal. 2006).

${ }^{41}$ Philip Morris USA v. Williams, 549 U.S. 346 (2007).
} 
explained that courts have some discretion in applying the State Farm ratio cap and that the three guideposts announced in BMW and reiterated in State Farm ultimately guide the reasonableness analysis of a given award.

\section{Exxon Mobil Corp. v. Alabama Department of Conservation and Natural Resources}

Unlike the previous two cases, Exxon Mobil Corp. v. Alabama Department of Conservation and Natural Resources (DCNR) does not involve the tobacco industry. ${ }^{42}$ This case began when Exxon leased land from the State of Alabama to develop natural gas reserves under Mobile Bay. ${ }^{43}$ After obtaining the leases, Exxon was supposed to pay Alabama royalties on the gas it extracted. Prior to the discovery of reserves under Mobile Bay, Alabama had used a standard lease for a number of years, but because of the value of the new reserves, the state rewrote the lease so that it better maximized the royalties owed to the state and was more favorable to the state in general. In the early 1980s, Exxon paid over $\$ 550$ million in nonrefundable bonuses to obtain leases for the reserves and agreed to pay royalties under the terms of the newly written leases. In 1993, the state discovered that Exxon was using certain practices when calculating royalties that the state believed were inconsistent with the procedures established in the leases. Exxon paid an additional $\$ 100$ million in royalties to the state, but the state demanded an additional $\$ 50$ million, which Exxon refused to pay. Exxon filed a suit seeking a declaratory judgment that it did not owe the additional amount, and the state counterclaimed under theories of fraud and breach of contract, seeking the additional amount and punitive damages.

At trial, the jury awarded the state over $\$ 60$ million in additional royalties and $\$ 27$ million in interest. Additionally, the jury imposed a punitive damages award of $\$ 3.42$ billion. As required by Alabama law, the court held a posttrial hearing on the amount of punitive damages but determined not to reduce the award. Exxon appealed the decision, and the appellate court ordered a new trial because the trial court admitted inadmissible evidence. A retrial took place in October 2003 (State Farm was decided in April 2003), and the jury awarded the state $\$ 63$ million in additional royalties, over $\$ 39$ million in interest, and $\$ 11.8$ billion in punitive damages. ${ }^{44}$ This verdict resulted in a punitive to compensatory damages ratio of approximately 187 . At a posttrial hearing, the court reduced the punitive damages award to $\$ 3.5$ billion but refused to grant a new trial.

Exxon appealed the new award, and the Supreme Court of Alabama detailed exactly what was required when paying royalties under the lease. The court upheld the lower court's judgments on the state's breach of contract claims but reversed the lower court on the fraud claims (the punitive damages in this case were based solely on the fraud claims). Under Alabama law, punitive damages could not be awarded for breach of contract claims,

\footnotetext{
${ }^{42}$ Exxon Mobil Corp. v. Alabama Dep't of Conservation \& Natural Res., 986 So. 2d 1093, 1097-98 (Ala. 2007).

${ }^{43}$ Exxon changed its name to Exxon Mobil in the course of this litigation, but we refer to that company as Exxon for conciseness.
}

${ }^{44}$ This is the relevant award for our above analysis of blockbuster awards. 
so the Supreme Court of Alabama overturned the punitive damages award and reduced the compensatory damages amount by the amount that was awarded for the fraud claims so that the final award was about $\$ 51$ million in total. Like Engle, this case involved a blockbuster punitive damages award, but after proceeding through the appeals process, that award ultimately did not survive.

\section{Middleton v. Collins}

Middleton v. Collins is a very unusual case for several reasons. Although the case involved the largest (unadjusted for inflation) punitive damages award in history, the plaintiffs never expected to recover any part of the award. In fact, the plaintiffs filed suit primarily to protest inaction by the local prosecutor's office. In 1998, 13-year-old Don Collins attacked eightyear-old Robert Middleton. Collins doused Middleton with gasoline and set him on fire, and Middleton suffered severe burns over every part of his body except for one foot. Middleton received treatment at Shriners hospital, so he did not incur any medical expenses. However, he spent the rest of his life in and out of the hospital and required multiple surgeries, which physicians described as unimaginably painful for Middleton. Middleton died in 2010 from cancer caused by the multiple skin grafts he required. In a deathbed confession, Middleton said that in addition to the gasoline attack, Collins had raped him.

Local prosecutors declined to file charges against Collins for his attack on Middleton. However, Middleton's parents filed a civil suit in 2011 (after State Farm was decided) against Collins on behalf of themselves and their son's estate for battery and wrongful death, among other claims. At trial, Collins did not retain counsel and filed a general denial pro se, but he never actually appeared in the courtroom-he was incarcerated for other crimes at the time. The court empaneled a jury, but the judge granted summary judgment on liability to the plaintiffs. The jury awarded each of Middleton's parents $\$ 60$ million and Middleton's estate $\$ 250$ million. The jury also awarded $\$ 150$ billion in punitive damages to the plaintiffs, which resulted in a punitive to compensatory damages ratio of approximately 405. However, the Middletons have publicly stated that they never expect to collect any part of this judgment and that they brought the civil case primarily to stir a public outcry and pressure the state to prosecute Collins for his actions in criminal court. Therefore, while Middleton did involve a blockbuster punitive damages award, that award is deceptive because even though the award is real, it represents more of a statement than a true award of damages to the plaintiffs.

\section{E. Discussion of the Four Largest Awards}

Collectively, the litigation histories of the four largest awards provide useful insight into blockbuster awards. Even the succinct overview of the cases provided here illustrates the complexity of the litigation, with three of the cases involving multiple appellate processes. More importantly, however, these four cases demonstrate that the initial blockbuster award is not always paid in its entirety. In all of the four largest cases except Middleton, the original blockbuster award was reduced or eliminated in subsequent litigation. Interestingly, 
State Farm played a role in the reductions in the two tobacco cases, so anecdotal evidence supports a meaningful State Farm effect. Even without State Farm, however, defendants often do not pay the full amount of the initial award. State law may, as it did in Exxon Mobil Corp., require the reduction of an award, or the defendant may simply refuse to pay. ${ }^{45}$

\section{Conclunsion}

Punitive damages can serve a useful role in the judicial system in theory, but evidence suggests that in some cases the awards may be very extreme. Blockbuster punitive damages awards exhibit an interesting type of unpredictability, as they follow a fat-tailed distribution. Predicting future awards when those awards follow a fat-tailed distribution can be particularly challenging if potential defendants assume that the awards follow more typical distributions, for example, normal. Contrary to typical expectations about the size of awards, the largest award in a fat-tailed distribution can be several times larger than the next largest award. Therefore, predicting and planning for very large punitive damages awards can be very difficult for potential defendants.

The U.S. Supreme Court has consistently recognized the lack of predictability in punitive damages awards in general, ${ }^{46}$ not just for blockbuster awards, and has provided guidelines to foster restraint in such awards. The current constitutional doctrine on punitive damages, anchored by the State Farm decision, has reduced blockbuster punitive damages awards. In the State Farm interaction versions of our models, State Farm altered the relationship between compensatory and punitive damages so that an additional dollar of compensatory damages generates less in additional punitive damages. This change in the relationship is particularly important since the amount of compensatory damages awarded has consistently been shown to be the best indicator of the amount of punitive damages awarded in a given case. In the intercept shift version of our models, State Farm moved the punitive damages distribution to the left, controlling for the level of compensatory damages.

State Farm has effectively "thinned" the fat tail of the distribution of blockbuster awards. While award amounts decreased in general after State Farm, this effect was most prominent for the upper end of the distribution of awards. Thus, State Farm made blockbuster awards more predictable to the extent that a thinner tail allows defendants to better anticipate their liability. However, despite the noticeable shift in the inverse cumulative distribution function of blockbuster awards after State Farm, these awards continue to be characterized by a fat-tailed distribution. Future courts and policymakers alike will want to take note of this distribution and the implications it has for the predictability of awards as the laws governing punitive damages change in the future.

\footnotetext{
${ }^{45}$ Obviously, refusing to pay damages can create other problems for a defendant, but if the defendant is already incarcerated, as he was in Middleton, these problems are likely to prove less salient.

${ }^{46}$ Exxon Shipping Co. v. Baker, 554 U.S. 471, 499 (2008) ("The real problem, it seems, is the stark unpredictability of punitive awards.").
} 


\section{REFERENCES}

Avraham, Ronen (2011) "Database of State Tort Law Reforms (DSTLR 4th)," Law and Economics Research Paper 184, University of Texas Law School.

Bremmer, Ian, \& Preston Keat (2009) The Fat Tail: The Power of Political Knowledge in an Uncertain World. New York: Oxford Univ. Press.

Del Rossi, Alison, \& W. Kip Viscusi (2010) "The Changing Landscape of Blockbuster Punitive Damages Awards," 12 American Law E Economics Rev. 116.

Eisenberg, Theodore, \& Michael Heise (2011) "Judge-Jury Difference in Punitive Damages Awards: Who Listens to the Supreme Court?," 8 J. of Legal Studies 325.

Eisenberg, Theodore, Neil LaFountain, Brian Ostrom, David Rottman, \& Martin T. Wells (2002) "Juries, Judges, and Punitive Damages: An Empirical Study," 87 Cornell Law Rev. 743.

Eisenberg, Theodore, \& Martin T. Wells (2006) "The Significant Association Between Punitive and Compensatory Damages in Blockbuster Cases: A Methodological Primer," 3 J. of Empirical Legal Studies 175 .

Halvorsen, Robert, \& Raymond Palmquist (1980) "The Interpretation of Dummy Variables in Semilogarithmic Equations," 70 American Economic Rev. 474.

Henderson, James A., \& Aaron D. Twerski (2010) "Reaching Equilibrium in Tobacco Litigation,” 62 South Carolina Law Rev. 67.

Hersch, Joni, \& W. Kip Viscusi (2004) "Punitive Damages: How Judges and Juries Perform," 33 J. of Legal Studies 1.

Kotz, Samuel, \& Saralees Nadarajah (2000) Extreme Value Distributions: Theory and Applications. London: Imperial College Press.

McMichael, Benjamin J. (2013) "Constitutional Limitations on Punitive Damages: Ambiguous Effects and Inconsistent Justifications,” 66 Vanderbilt Law Rev. 961.

Polinsky, A. Mitchell, \& Steven Shavell (1998) "Punitive Damages: An Economic Analysis," 111 Harvard Law Rev. 869.

Sunstein, Cass, Reid Hastie, John Payne, David Schkade, \& W. Kip Viscusi (2002) Punitive Damages: How Juries Decide. Chicago, IL: Univ. of Chicago Press.

VerdictSearch (2010) VerdictSearch Top 100 Verdicts of 2009. New York: VerdictSearch.

(2011) VerdictSearch Top 100 Verdicts of 2010. New York: VerdictSearch.

(2012) VerdictSearch Top 100 Verdicts of 2011. New York: VerdictSearch.

(2013) VerdictSearch Top 100 Verdicts of 2012. New York: VerdictSearch.

Viscusi, W. Kip (2004) “The Blockbuster Punitive Damages Awards," 53 Emory Law J. 1405.

Viscusi, W. Kip, \& Richard J. Zeckhauser (2011) "Deterring and Compensating Oil Spill Catastrophes: The Need for Strict and Two-Tier Liability," 64 Vanderbilt Law Rev. 1717.

Yu, Hai-Chin, \& Ming-Chang Huang (2004) "Statistical Properties of Volatility in Fractal Dimension and Probability Distribution Among Six Stock Markets," 14 Applied Financial Economics 1087. 